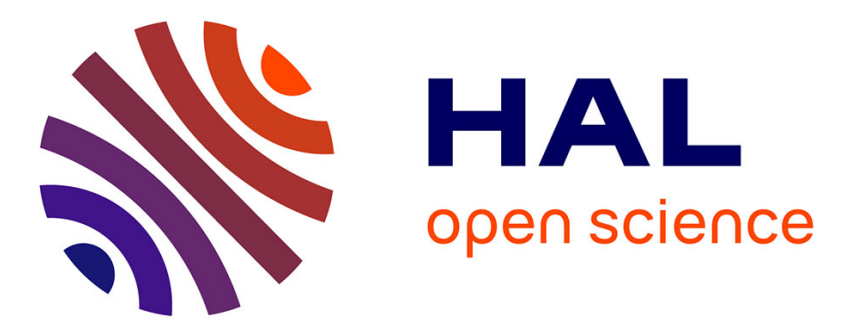

\title{
A Thermomorphic Polyethylene-Supported Imidazolium Salt for the Fixation of CO 2 into Cyclic Carbonates
}

Kevin Grollier, Nam Duc Vu, Franck d'Agosto, Nam Duc Vu, Killian Onida, Ayman Akhdar, Sébastien Norsic, Franck D ' Agosto, Christophe Boisson, Nicolas Duguet

\section{To cite this version:}

Kevin Grollier, Nam Duc Vu, Franck d'Agosto, Nam Duc Vu, Killian Onida, et al.. A Thermomorphic Polyethylene-Supported Imidazolium Salt for the Fixation of CO 2 into Cyclic Carbonates. Advanced Synthesis and Catalysis, 2020, 362 (8), pp.1696-1705. 10.1002/adsc.202000032 . hal-02972732

\section{HAL Id: hal-02972732 https://hal.science/hal-02972732}

Submitted on 23 Nov 2020

HAL is a multi-disciplinary open access archive for the deposit and dissemination of scientific research documents, whether they are published or not. The documents may come from teaching and research institutions in France or abroad, or from public or private research centers.
L'archive ouverte pluridisciplinaire HAL, est destinée au dépôt et à la diffusion de documents scientifiques de niveau recherche, publiés ou non, émanant des établissements d'enseignement et de recherche français ou étrangers, des laboratoires publics ou privés. 


\title{
A Thermomorphic Polyethylene-Supported Imidazolium Salt for the Fixation of $\mathrm{CO}_{2}$ into Cyclic Carbonates
}

\author{
Kevin Grollier, ${ }^{\mathrm{a}}$ Nam Duc Vu, ${ }^{\mathrm{a}}$ Killian Onida, ${ }^{\mathrm{a}}$ Ayman Akhdar, ${ }^{\mathrm{a}}$ Sébastien Norsic, ${ }^{\mathrm{b}}$ \\ Franck D’Agosto, ${ }^{\mathrm{b}}$ Christophe Boisson, ${ }^{\mathrm{b}}$ and Nicolas Duguet ${ }^{\mathrm{a}, *}$
}

a Université de Lyon, Université Claude Bernard Lyon 1, CNRS, INSA-Lyon, CPE-Lyon, Institut de Chimie et Biochimie Moléculaires et Supramoléculaires, ICBMS, UMR 5246, Equipe CAtalyse, SYnthèse et ENvironnement (CASYEN), Bâtiment Lederer, 1 rue Victor Grignard, F-69622 Villeurbanne cedex, France. Dr Nicolas Duguet: +33(0) 472448 507, nicolas.duguet@univ-lyon1.fr

b Université de Lyon, Univ. Lyon 1, CPE Lyon, CNRS UMR 5265, Laboratoire de Chimie Catalyse Polymères et Procédés (C2P2), Equipe LCPP, Bat 308F, 43 Bd du 11 Novembre 1918, F-69616 Villeurbanne, France.

Received: ((will be filled in by the editorial staff))

Supporting information for this article is available on the WWW under http://dx.doi.org/10.1002/adsc.201\#\#\#\#\#\#.((Please delete if not appropriate))

\begin{abstract}
An imidazolium catalyst supported on thermomorphic polyethylene (PE) was prepared from 1methylimidazole and polyethylene iodide (PE-I). The catalyst was characterized by ${ }^{1} \mathrm{H}$ and ${ }^{13} \mathrm{C}$ NMR, SEC and MALDI-ToF mass spectrometry. Its catalytic activity was evaluated in the ring-opening of epoxides with carbon dioxide to give cyclic carbonates under solvent-free conditions. The catalyst proved to be active at low catalyst loading (down to $0.1 \mathrm{~mol} \%$ ) and allows the reaction to occur at low $\mathrm{CO}_{2}$ pressure
\end{abstract}

(1-5 bar) and moderate temperature $\left(100^{\circ} \mathrm{C}\right)$. A range of terminal and internal epoxides was converted to the corresponding cyclic carbonates with high yields and selectivities. The recyclability of the catalyst was studied and no significant loss of activity was observed after 5 runs.

Keywords: Polyethylene; Organocatalysis; carbon dioxide; epoxides; cyclic carbonates

\section{Introduction}

Carbon dioxide is the most important waste produced by human activities due to the massive utilization of fossil resources for the production of energy and raw materials. Moreover, carbon dioxide, as a greenhouse gas, has an important impact on the climate change ${ }^{1}$ but also on the biodiversity due to the acidification of the oceans. ${ }^{2}$ In February 2018, a high concentration of $408 \mathrm{ppm}$ of $\mathrm{CO}_{2}$ (World average) was reported. ${ }^{3}$ One way to decrease this concentration is the capture and storage of carbon dioxide, ${ }^{4}$ notably using Metal-Organic Frameworks (MOFs). ${ }^{5}$ An alternative way is to use $\mathrm{CO}_{2}$ as a non-toxic, cheap and abundant $\mathrm{C} 1$ building block. ${ }^{6}$ For instance, $\mathrm{CO}_{2}$ is mainly used for the direct carboxylation of organic substrates, ${ }^{7}$ for incorporation into heterocycles ${ }^{8}$ and for methylation reactions. ${ }^{9}$ Additionally, carbon dioxide is already used to produce urea on an industrial scale (120 Mt/year). ${ }^{10}$ Another industrial application is the synthesis of propylene carbonate from propylene oxide and $\mathrm{CO}_{2}$ with $100 \%$ atom economy. Generally, cyclic carbonates can be used as non-toxic solvents, ${ }^{11}$ electrolytes for lithium batteries ${ }^{12}$ and as precursors for the preparation of polycarbonates ${ }^{13}$ and nonisocyanates polyurethanes (NIPUs). ${ }^{14}$ These different applications make the preparation of cyclic carbonates a very active field. ${ }^{15}$ The carbon of $\mathrm{CO}_{2}$ is at the most oxidized state engendering an important thermodynamic stability. Consequently, the utilization of a catalyst is mandatory to activate it. A lot of catalytic systems have been described in the literature for the preparation of carbonates from $\mathrm{CO}_{2}{ }^{16}$ Metalbased catalysts such as Metal-Organic Frameworks, ${ }^{17}$ Salen, ${ }^{18}$ salophen, ${ }^{19}$ porphyrin,${ }^{20}$ scorpionate, ${ }^{21}$ triphenolate ${ }^{22}$ complexes usually offer excellent activities with a low catalyst loading. Alternatively, metal-free approaches have been reported in the literature $^{23}$ mainly using single-component organocatalysts such as ammonium, ${ }^{24}$ phosphonium, ${ }^{25}$ and imidazolium ${ }^{26}$ salts or other organocatalytic systems based on polyols ${ }^{27}$ and polyphenols, ${ }^{28} \mathrm{DBU}$ derived salts, ${ }^{29}$ amongst others. ${ }^{23}$ New organocatalysts have also emerged such as squaramides, ${ }^{30}$ ascorbic acid, ${ }^{31}$ organic scorpionates, ${ }^{32}$ and boron-based systems. ${ }^{33}$ More recently, metal-free and halide-free catalysts have also been developed, ${ }^{34}$ highlighting the intense research efforts on this topic. Organocatalysts are usually inexpensive but often require a higher catalyst loading than metal-based catalysts. Another drawback of organocatalysts is related to their difficult separation from the reaction mixture, thus compromising the recycling. To avoid this issue, supported versions have been described using various insoluble supports such as polystyrene, ${ }^{35}$ silica ${ }^{36}$ or biopolymers such as cellulose ${ }^{37}$ and chitosan. ${ }^{38}$ Many other heterogeneous systems were also reported to 
efficiently catalyse the reaction. ${ }^{39}$ However, except in some cases, ${ }^{40}$ the catalytic activity of supported catalysts is usually lower than their non-supported versions, mainly due to diffusion problems. ${ }^{41}$ In this context, thermomorphic polyethylene (PE) could be a good alternative to insoluble supports due to its original physical properties. Thermomorphic PE is solid at room temperature but becomes liquid above its melting temperature (about $100-120^{\circ} \mathrm{C}$ ) and could be solubilized in aromatic solvents (around $80-90^{\circ} \mathrm{C}$ ). This property permits an easier recycling of the catalyst while keeping a good activity, thus offering the benefits of both homogeneous and heterogeneous catalysts. ${ }^{42}$ Only two catalysts supported on thermomorphic PE were described in the literature. Beirgbreiter et al. reported a ruthenium-based catalyst supported on PE for the olefin ring-closing metathesis ${ }^{43}$ and Boisson, Thieuleux et al. described an iridium-based catalyst grafted on PE for the D/H exchange. ${ }^{44}$ To the best of our knowledge, endfunctionalized thermomorphic PE has never been used as support for organocatalysts. Herein, we report the synthesis and characterization of an imidazolium organocatalyst supported on thermomorphic polyethylene for the preparation of cyclic carbonates using $\mathrm{CO}_{2}$ (Scheme 1).

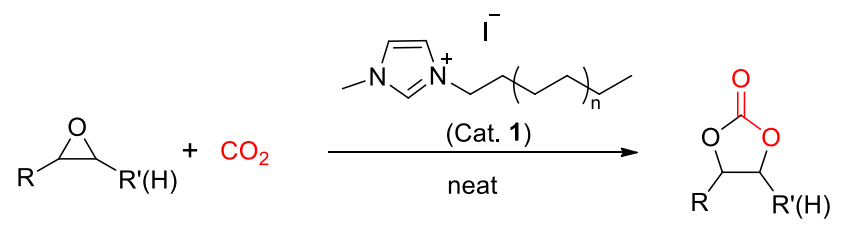

$\mathrm{R}, \mathrm{R}^{\prime}=$ alkyl, aryl

Scheme 1. Synthesis of carbonates from $\mathrm{CO}_{2}$ using a thermomorphic PE-supported organocatalyst.

\section{Results and Discussion}

First, polyethylene iodide (PE-I) was prepared by polymerization of ethylene in the presence of a neodymium complex ${ }^{45}$ and was obtained with $92 \%$ functionalization (the remaining $8 \%$ are nonfunctionalized PE). An number average degree of polymerization $\left(D P_{\mathrm{n}}\right)$ of 36 was obtained from the NMR analysis of the PE-I (see ESI). Due to the fact that PE derivatives are not soluble in any solvent at room temperature, no purification by column chromatography can be done. So, the challenge of using this material is to obtain quantitative functionalization. The thermomorphic catalyst was synthesized at $120^{\circ} \mathrm{C}$ from commercially available 1 methylimidazole (6 equiv.) and PE-I (Scheme 2 ).

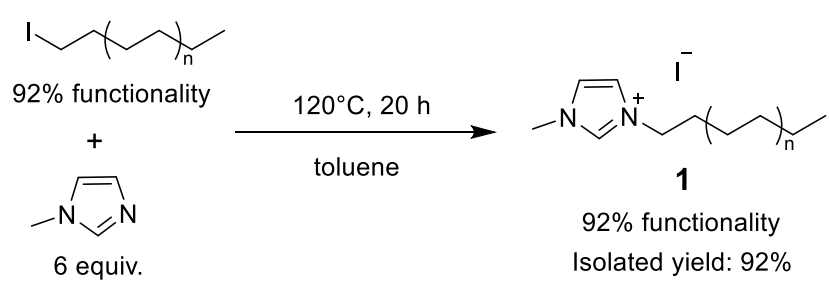

Scheme 2. Preparation of catalyst 1.

The complete conversion of PE-I has been proved by ${ }^{1} \mathrm{H}$ NMR and 3-methyl-1-polyethyleneimidazolium iodide 1 was obtained in $92 \%$ isolated yield. Catalyst 1 was characterized by ${ }^{1} \mathrm{H}$ and ${ }^{13} \mathrm{C}$ NMR, SEC and MALDI-ToF mass spectroscopy. From ${ }^{1} \mathrm{H}$ and ${ }^{13} \mathrm{C}$ NMR spectra, the apparition of the characteristic proton at $9.79 \mathrm{ppm}$ and carbon at $138.0 \mathrm{ppm}$ (spectrum in ESI) clearly indicate the formation of the imidazolium core (Figure 1).

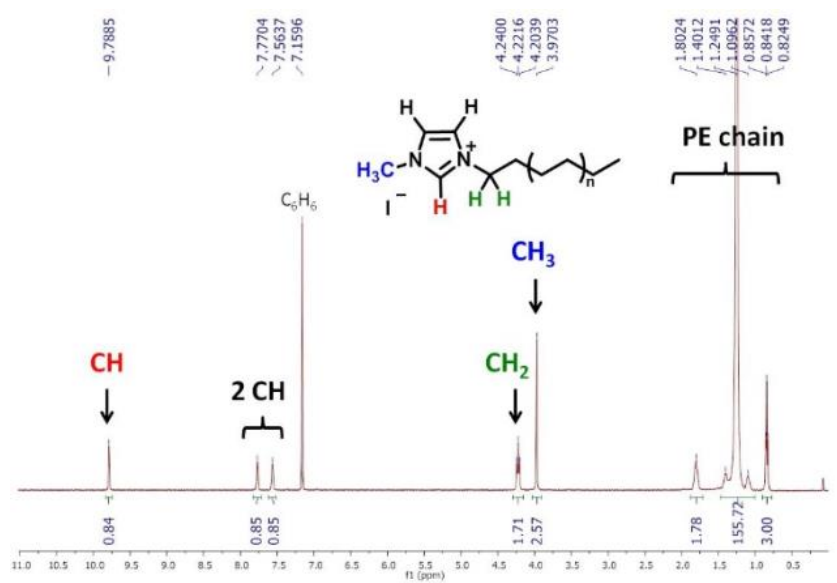

Figure 1. ${ }^{1} \mathrm{H}$ NMR $\left(\mathrm{TCE} / \mathrm{C}_{6} \mathrm{D}_{6} 2: 1_{\mathrm{v} / \mathrm{v}}, 500 \mathrm{MHz}, 363 \mathrm{~K}, 128\right.$ scans) of the polyethylene-supported imidazolium.

A functionality of about $92 \%$ was calculated based on the proton integrations (calculation method detailed in ESI). A $D P_{\mathrm{n}}$ of 42 was also calculated based on NMR data (ESI) which gave an average molar mass of $M_{\mathrm{n}}=1385 \mathrm{~g} \mathrm{~mol}^{-1}$. In regards to the precursor PE-I, the slightly higher $D P_{\mathrm{n}}$ measured for 1 can be explained by the loss of a fraction of low molar mass polymer during the purification of the product. The SEC of $\mathbf{1}$ (performed at high temperature in trichlorobenzene) was also carried out but the results could not be exploited unambiguously due to the presence of the charged imidazolium core as sometimes observed for PE chains carrying charged end group. ${ }^{46}$ MALDI-ToF mass spectrometry (MALDI-ToF MS) of the same sample is also given in Figure 2. Three different populations can be observed. The red one corresponds to catalyst 1; for a DP of 20, a mass of $699.75 \mathrm{~m} / \mathrm{z}$ was required $\left(\mathrm{C}_{48} \mathrm{H}_{95} \mathrm{~N}_{2}\right)$ and a mass of $699.7 \mathrm{~m} / \mathrm{z}$ was experimentally found (Figure $2 \mathrm{a}$ and $2 \mathrm{~b}$ ). The two other populations (blue and green curves) correspond to two fragments with a loss of mass of $14 \mathrm{Da}$ and 12 $\mathrm{Da}$, respectively. The loss of $14 \mathrm{Da}$ would result from 
the cleavage of the $\mathrm{N}-\mathrm{CH}_{3}$ and the loss of $12 \mathrm{Da}$ could result from the fragmentation of the imidazolium core $\left(\mathrm{M}^{+}-\mathrm{CH}+\mathrm{H}^{+}\right)$. The accordance between experimental and calculated isotopic abundance of the catalyst for a $\mathrm{DP}=20$ confirms the nature of the red population
(Figure 2, b and c). However, the average molar mass of the polymer could not be accurately determined by MALDI-ToF MS. Indeed, the chains that are vaporized are condition-dependent, ${ }^{46,47}$ in our case, only short chains were analyzed.
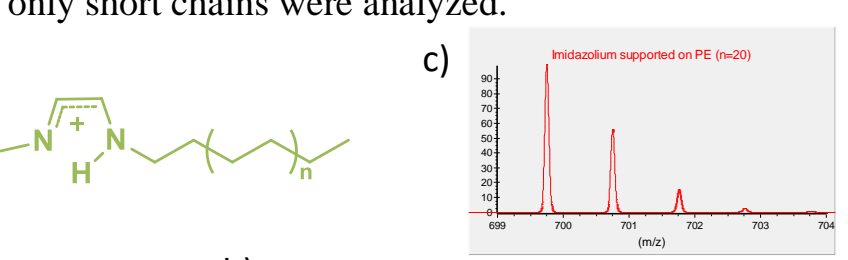

a)

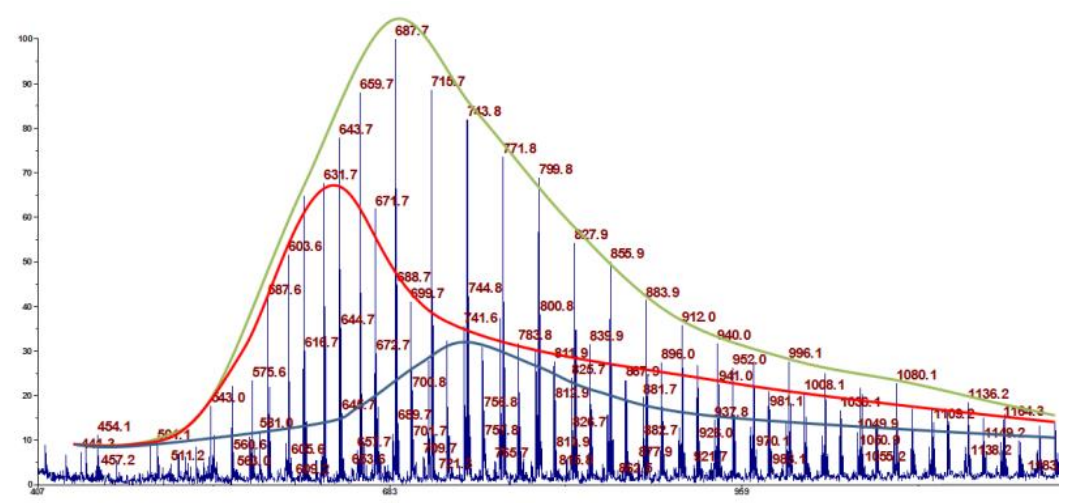

b)

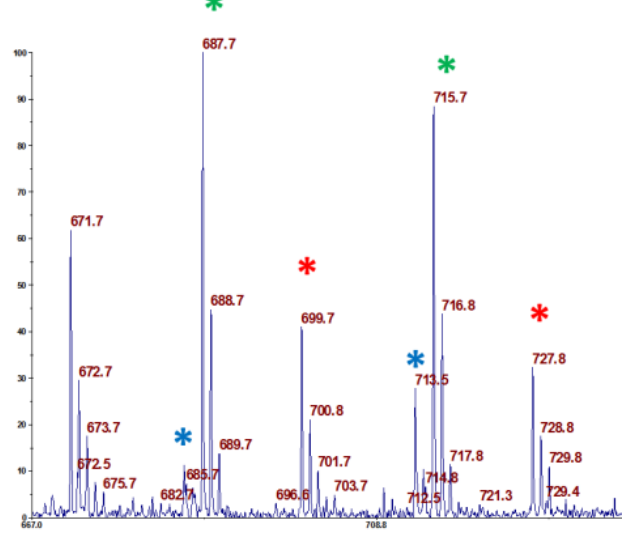

Figure 2. a) MALDI-ToF MS of catalyst 1. b) Zoom between $670-740 \mathrm{~m} / \mathrm{z}$. c) Theoretical isotopic abundance (calculated by IsoPro) for the $699.7 \mathrm{~m} / \mathrm{z}$ peak (DP=20).

In addition, MALDI-ToF MS is not quantitative as attested by the discrepancies between the quantitative functionalization of PE-I observed by ${ }^{1} \mathrm{H}$ NMR and the presence of additional populations resulting from fragmentation during MALDI-ToF MS analyses. Overall, all analysis confirmed the expected structure of the thermomorphic PE supported imidazolium 1. Finally, the thermomorphic character of catalyst $\mathbf{1}$ was investigated. At room temperature, the catalyst is a white solid (Figure 3, a) but it becomes liquid above $110^{\circ} \mathrm{C}$ when heated neat (Figure 3, b). This behaviour correlates well with the DSC data showing that the catalyst is a crystalline material, which has a fusion temperature of about $115^{\circ} \mathrm{C}$ (at peak) and a crystallisation temperature of about $104^{\circ} \mathrm{C}$ (at peak) (see ESI).

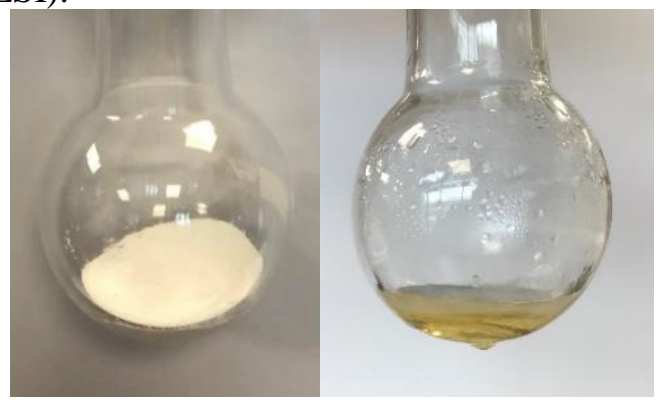

Figure 3. a) Catalyst 1 at room temperature. b) Catalyst 1 at $110^{\circ} \mathrm{C}$ (after being melt around $120^{\circ} \mathrm{C}$, then cooled to $\left.110^{\circ} \mathrm{C}\right)$.

Advantageously, this thermomorphic organocatalyst can be synthesized through a singlestep operation on a multi-gram scale.

The catalytic activity of $\mathbf{1}$ was evaluated for the formation of cyclic carbonates from $\mathrm{CO}_{2}$ and epoxides. The optimization of the reaction parameters was carried out using the ring-opening of styrene oxide 2 (SO) into styrene carbonate $\mathbf{3}$ (SC) as a model reaction (Table 1). A fixed temperature of $100^{\circ} \mathrm{C}$ was chosen to fully exploit the thermomorphic character of the catalyst. At this temperature, the polymer-supported organocatalyst and the reagents are completely miscible. Moreover, all the reactions were performed in solvent-free conditions. At 20 and 10 bar of $\mathrm{CO}_{2}$, the conversion of SO 2 was almost complete after 4 hours using only $1 \mathrm{~mol} \%$ of catalyst. The selectivity was $>99 \%$, thus giving a yield of SC 3 of about 95$97 \%$ (Table 1, entries 1-2). Then, in order to determine the limits of the catalytic activity, the catalyst loading was decreased from 1 to $0.1 \mathrm{~mol} \%$, but these conditions did not permit to reach more than $85 \%$ yield (Table 1, entries 3-5). By increasing the reaction time to 16 hours, almost quantitative yields (96-97\%) can 
be reached using 0.4 and $0.2 \mathrm{~mol} \%$ of catalyst while only $78 \%$ of SC was obtained for $0.1 \mathrm{~mol} \%$ (Table 1 , entries 3-5, results in brackets). From these results, we decided to keep the catalyst loading at $0.4 \mathrm{~mol} \%$ for further optimization in order to apply robust conditions to a wide range of epoxides.

Table 1. Optimization of the reaction conditions for the opening of SO into SC. ${ }^{\mathrm{a}}$

\begin{tabular}{llllll}
\hline & & & & \\
\cline { 3 - 5 } & & & & & \\
\hline
\end{tabular}

a) Reaction conditions: $45-\mathrm{mL}$ stainless steel autoclave, epoxide 2 (1.05 g, $8.74 \mathrm{mmol}), 100^{\circ} \mathrm{C}$. b) Yields were determined by ${ }^{1} \mathrm{H}$ NMR of the crude reaction mixture. Selectivity is always $>99 \%$. c) 16 hours of reaction. d) Balloon of $\mathrm{CO}_{2}$.

Moreover, a similar yield of $96 \%$ was obtained by using only 5 bar of $\mathrm{CO}_{2}$ (Table 1 , entry 6). Interestingly, the reaction can also proceed smoothly under ambient $\mathrm{CO}_{2}$ pressure (balloon) using $0.4 \mathrm{~mol} \%$ of catalyst 1 to give SC with $88 \%$ yield (Table 1, entry 7). Finally, a blank experiment was performed without any catalyst and only traces of carbonate $\mathbf{3}$ was observed, thus confirming the importance of the catalyst to promote the reaction (Table 1 , entry 8).

Subsequently, the optimized conditions $[0.4 \mathrm{~mol} \%$ of 1 , neat, $100^{\circ} \mathrm{C}, 16 \mathrm{~h}, 5 \mathrm{bar}$ of $\mathrm{CO}_{2}$ ] were applied for the formation of cyclic carbonates from a range of terminal epoxides (Figure 4).

First, styrene oxide gave carbonate $\mathbf{3}$ with $89 \%$ isolated yield. Glycidol was fully converted, but the selectivity of carbonate $\mathbf{4}$ did not reach more than $45 \%$ due to the formation of a polymer. Indeed, at high temperature in the presence an acidic proton, glycidol can easily polymerize to polyethers, as already reported in the literature. ${ }^{48}$ To circumvent this problem, 1,2-epoxy-3-phenoxypropane was used as a starting material and the corresponding carbonate $\mathbf{5}$ was obtained with $95 \%$ isolated yield. For the other terminal epoxides, the catalytic system was highly selective (>99\%) toward the formation of cyclic carbonates and the NMR yield reached $99 \%$ in all cases. Epichlorohydrin was fully converted to give carbonate 6 with $86 \%$ yield. Similarly, epifluorohydrin and epibromohydrin were successfully converted to carbonates 7-8 with 99 and 92\% isolated yield, respectively. The reaction was also carried out on a range of terminal epoxides bearing a linear alkyl chain. With propylene oxide and 1,2-epoxybutane, the conversion was full and carbonates 9-10 were isolated with moderate yields (62-69\%). Under the standard conditions, the conversion of 1,2-epoxyhexane and 1,2-epoxyoctane only reached 75 and $78 \%$, respectively. These results show that the increase of the alkyl chain length slightly decreases the catalytic activity, probably due to the combination of steric and solubility issues. Increasing the catalyst loading to 1 mol\% allowed to fully convert these two epoxides and the corresponding carbonates $\mathbf{1 1 - 1 2}$ were isolated with $92 \%$ yield. The presence of a double bond is well tolerated and carbonate $\mathbf{1 3}$ was isolated with $81 \%$ yield. Finally, a bis-epoxide was converted to bis-carbonate 14 with an excellent $97 \%$ isolated yield. Noteworthy, bis-carbonates are excellent building-block for the preparation of non-isocyanate polyurethanes (NIPUs).

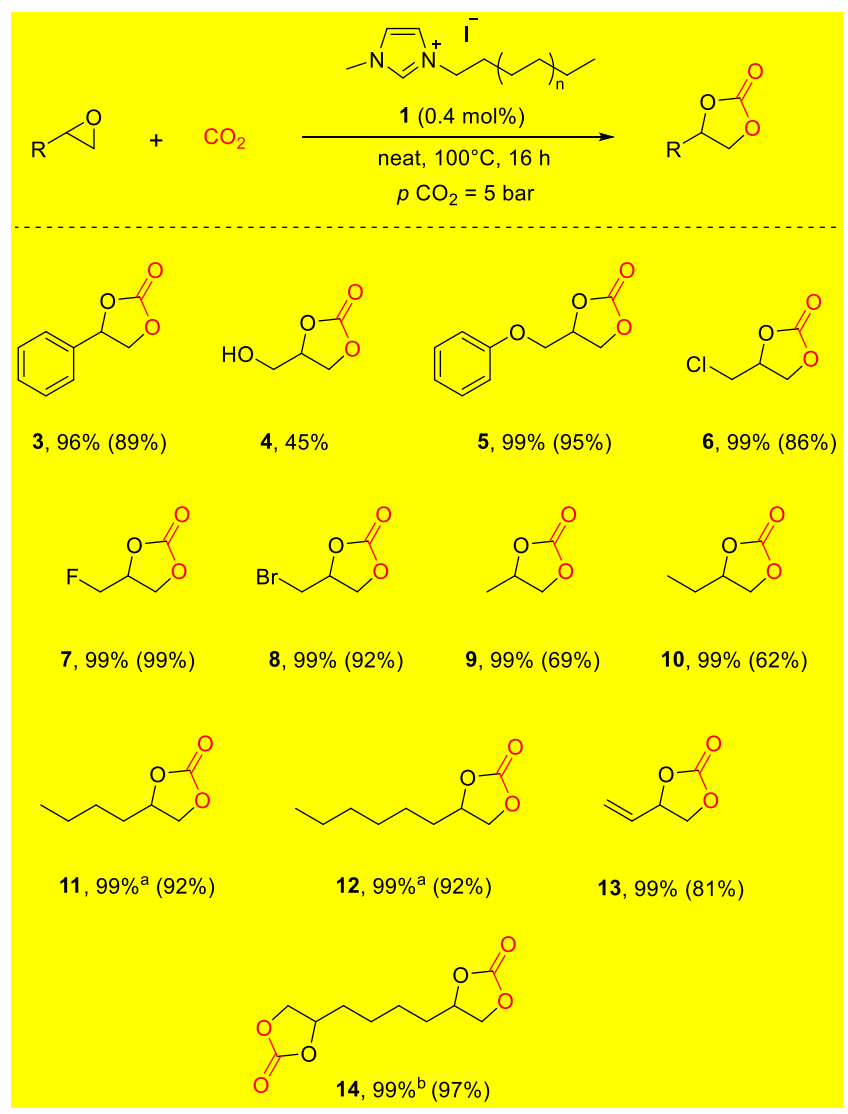

Figure 4. Evaluation of the substrate scope using terminal epoxides. Reaction conditions: 45-mL stainless steel autoclave, epoxides (1 equiv.), catalyst $1(0.4 \mathrm{~mol} \%)$, neat, $100^{\circ} \mathrm{C}, 16 \mathrm{~h}, p\left(\mathrm{CO}_{2}\right)=5$ bar. ${ }^{\mathrm{a}}$ Using $1 \mathrm{~mol} \%$ of $1 .{ }^{\mathrm{b}} 0.4$ mol\% of catalyst / epoxide function was used. Yields were determined by ${ }^{1} \mathrm{H}$ NMR of the crude reaction mixture. Isolated yields are given in brakets. All selectivities are > $99 \%$ except for glycidol (45\%).

The conversion of more challenging substrates such as 1,2-disubstituted and cyclic epoxides was next studied using catalyst 1 (Figure 5). First, the reaction was carried out on trans-stilbene oxide under the 
standard conditions, but only up to $5 \%$ of the corresponding carbonate was obtained. Not surprisingly, the reactivity of internal epoxides is usually lower compared to the terminal ones as reported in the literature. ${ }^{49}$ As a result, the reaction conditions were hardened to reach a satisfying conversion of trans-stilbene oxide (see Table S1 in ESI). Using $4 \mathrm{~mol} \%$ of $\mathbf{1}$ and increasing the $\mathrm{CO}_{2}$ pressure to $10 \mathrm{bar}$, the conversion of trans-stilbene oxide reached $82 \%$ after 40 hours. However, carbonate 15 was obtained with only $71 \%$ selectivity. Indeed, the presence of 2-phenylacetophenone has been observed by ${ }^{1} \mathrm{H}$ NMR, and was formed with $24 \%$. The formation of this ketone could be explained by a Meinwald rearrangement ${ }^{50}$ catalyzed by the imidazolium species. A similar rearrangement was also observed starting from cis-stilbene oxide and the corresponding carbonate $\mathbf{1 5}$ was obtained with comparable yield $(62 \%)$ and selectivity $(71 \%)$. Using the same conditions, high conversions of cyclopentene and cyclohexene oxides were reached and cyclic carbonates 16-18 were obtained high yields (85-90\%).

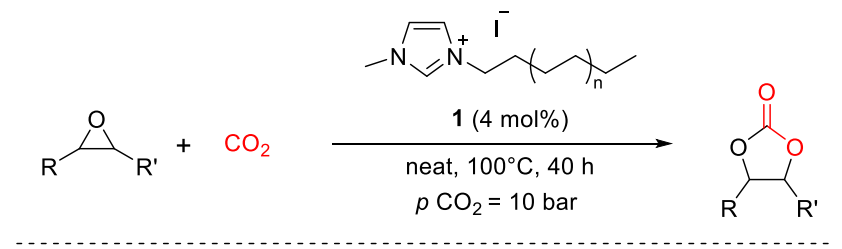

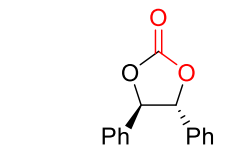

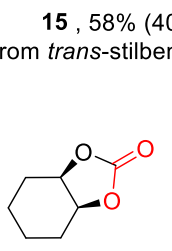

$17,85 \%(34 \%)$

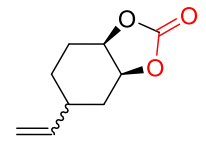

$18,90 \%(52 \%)$ $(\mathrm{dr}=43: 57)$

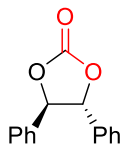

$15,62 \%(38 \%)$ (from cis-stilbene oxide)

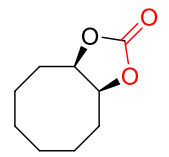

$19,10 \%$

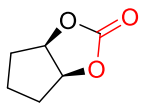

$16,86 \%(58 \%)$

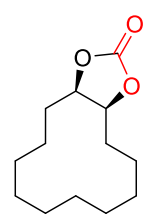

20, $\mathrm{NR}^{\mathrm{a}}$
Figure 5. Evaluation of the substrate scope using internal epoxides. Reaction conditions: 45-mL stainless steel autoclave, epoxide (1 equiv.), catalyst 1 (4 mol\%), neat, $100^{\circ} \mathrm{C}, 40 \mathrm{~h}, p\left(\mathrm{CO}_{2}\right)=10$ bar. ${ }^{\text {a }} 72 \mathrm{~h}$ reaction. NR: No Reaction. Yields were determined by ${ }^{1} \mathrm{H}$ NMR of the crude reaction mixture. All selectivities are > $99 \%$ except for trans- and cis-stilbene oxides $(71 \%)$. Isolated yields obtained after purification by column chromatography are presented in brakets.

It should be noted that carbonate $\mathbf{1 8}$ was obtained as a 43:57 mixture of diastereoisomers due to the presence of cis/trans-isomers (in similar ratio) in the starting material. The reaction was also performed on cyclooctene oxide, however, the corresponding carbonate 19 was only obtained with $10 \%$ yield. Finally, for cyclododecene oxide, no traces of carbonate 20 has been detected even after 72 hours. It should be noted that such behaviour has already been reported before. ${ }^{51}$ The lower reactivity can be explained by a preferred twisted conformation of the fused 8- or 12-membered ring, making the ringopening more difficult or even impossible under the chosen reaction conditions.

The mechanism of the epoxide ring opening into carbonates with imidazolium salts is already wellknown and relatively well described in the literature. ${ }^{23 \mathrm{c}}$ In catalyst $\mathbf{1}$, the iodide is a good candidate to open the epoxide as it is a good nucleophilic and non-basic counter-anion. Moreover, the presence of the PE chain can enhance this nucleophilicity: the combination of steric effects and the non-polar properties of the chain allows a better dissociation of the imidazolium ion pair. Indeed, it has been previously reported that the number of carbons of the linear alkyl chain carried by the imidazolium core has an influence in term of reactivity. ${ }^{26 \mathrm{~b}}$ From methyl to dodecyl, it was observed that the longer the chain, the more reactive the catalyst. ${ }^{52}$ To verify that this phenomenon is also true in our case, a comparison between catalyst $\mathbf{1}$ and a shorter analogue $\mathbf{2 1}$ was performed using styrene oxide 2 as a model substrate. The reaction was carried out with $0.4 \mathrm{~mol} \%$ of catalyst at $100^{\circ} \mathrm{C}$ under 10 bar of $\mathrm{CO}_{2}$ (Scheme 4).

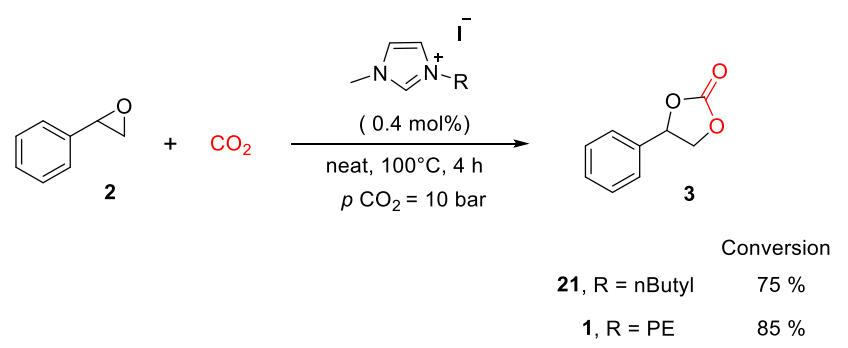

Scheme 4. Comparison of catalysts 21 and $\mathbf{1}$. The selectivity is $>99 \%$ for these two reactions. Conversion and selectivity were determined by ${ }^{1} \mathrm{H} \mathrm{NMR}$ of the crude reaction mixture.

With 1-butyl-3-methylimidazolium iodide 21, the conversion reached $75 \%$, while using catalyst $\mathbf{1}$, it increased to $85 \%$. This significant difference of reactivity confirms the positive influence of the long PE alkyl chain. Moreover, for the systems that incorporate long alkyl chains, the miscibility of $\mathbf{1}$ with the other reactants (epoxides and $\mathrm{CO}_{2}$ ) may significantly improve, giving better overall kinetics. Herein, we demonstrate the advantages of the PE supported organocatalyst: while its recovery is eased by the insolubility of PE at low temperature, this supported version is more reactive than the homogeneous one, which is in sharp contrast with the lower reactivity expected from a supported catalyst. ${ }^{41}$

The recyclability of catalyst $\mathbf{1}$ was investigated using styrene oxide as a model substrate (Figure 6). 


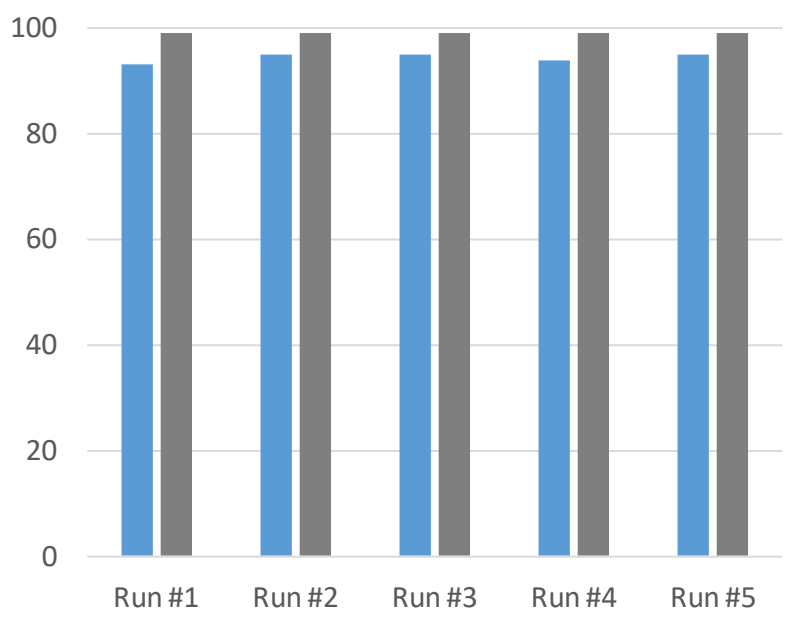

Figure 6. Study of the recyclability of catalyst $\mathbf{1}$. Reaction conditions: 45-mL stainless steel autoclave, catalyst 1 (1 mol\%), styrene oxide 2 (1.05 g, $8.74 \mathrm{mmol})$, neat, $100^{\circ} \mathrm{C}$, $4 \mathrm{~h}, p\left(\mathrm{CO}_{2}\right)=10$ bar. Blue: conversion. Grey: selectivity. Conversions and selectivities were determined by ${ }^{1} \mathrm{H}$ NMR of the crude reaction mixture.

After each reaction, the catalyst was filtered, washed and dried before re-use. The results show that both the conversion (93-95\%) and the selectivity (99\%) were maintained over five runs, thus indicating that neither deactivation nor degradation of the catalyst occurred under these conditions. To further verify this, the ${ }^{1} \mathrm{H}$ NMR of the used catalyst after five runs was also performed and compared with those of the fresh catalyst (see ESI). Satisfyingly, no detectable sign of degradation was observed, thus highlighting its high robustness and stability.

In order to further highlight the reactivity of catalyst 1, its performances were compared with selected recent homogeneous and heterogeneous organocatalytic systems (Table 2). ${ }^{53}$ For better comparison, the reaction was carried out with propylene oxide using $0.4 \mathrm{~mol} \%$ of catalyst 1 at $100^{\circ} \mathrm{C}$ for 4 hours. Under these conditions, the ${ }^{1} \mathrm{H}$ NMR yield of propylene carbonate 9 reached $79 \%$, thus giving a TON of 198 and a TOF of $49 \mathrm{~h}^{-1}$ (Table 2, entry 1). These results are comparable with the catalytic performances of phosphorus ylide- $\mathrm{CO}_{2}$ adducts reported by Lu (Table 2, entry 2). ${ }^{54}$ This demonstrates that thermomorphic polyethylene-supported organocatalyst 1 exhibit similar performances that homogeneous single component organocatalysts. Better results were reported by Kleij using squaramides but in the presence of tetrabutylammonium iodide co-catalyst (Table 2, entry 3). ${ }^{30 \mathrm{a}}$ For other comparison, fully recyclable, heterogeneous organocatalytic systems such as polystyrene-supported resorcinarenes ${ }^{28 c}$ and functional ionic polymers (FIP-Im) ${ }^{55}$ gave TOF values of 5.5 and $2 \mathrm{~h}^{-1}$, respectively (Table 2, entries 4-5).

Table 2. Comparison of catalytic activites with selected (supported-)organocatalytic systems. ${ }^{\text {a }}$

\begin{tabular}{|c|c|c|c|c|c|c|c|c|}
\hline Entry & Catalytic system & S.M. & $\begin{array}{l}\text { Cat. } \\
\text { loading } \\
(\operatorname{mol} \%)\end{array}$ & $\begin{array}{l}\text { Reaction } \\
\text { conditions }\end{array}$ & $\begin{array}{l}\text { Conv./ } \\
\text { Yield } \\
(\%)\end{array}$ & TON & $\begin{array}{l}\text { TOF } \\
\left(h^{-1}\right)\end{array}$ & Recycling \\
\hline 1 & $\begin{array}{l}\text { PE-Im } \\
\text { This work }\end{array}$ & PO & 0.4 & $\begin{array}{l}\text { neat, } 100^{\circ} \mathrm{C}, 4 \mathrm{~h} \\
p\left(\mathrm{CO}_{2}\right)=5 \mathrm{bar}\end{array}$ & $79^{b}$ & 198 & 49 & 5 runs $(\mathrm{SO})$ \\
\hline 2 & $\begin{array}{l}\mathrm{CO}_{2} \text {-Phosphorus ylides } \\
\text { adducts, } \\
\mathrm{Lu},(2015)^{54}\end{array}$ & $\mathrm{PO}$ & 0.5 & $\begin{array}{l}\text { neat, } 100^{\circ} \mathrm{C}, 4 \mathrm{~h} \\
p\left(\mathrm{CO}_{2}\right)=20 \mathrm{bar}\end{array}$ & $78^{b}$ & 156 & 39 & Homogeneous \\
\hline 3 & $\begin{array}{l}\text { Squaramides / TBAI } \\
\text { Kleij, }(2017)^{30 a}\end{array}$ & $\mathrm{EH}$ & $2 / 2$ & $\begin{array}{l}\text { neat, } 80^{\circ} \mathrm{C}, 0.5 \mathrm{~h} \\
p\left(\mathrm{CO}_{2}\right)=10 \mathrm{bar}\end{array}$ & $85^{b}$ & 42 & 85 & Homogeneous \\
\hline 4 & $\begin{array}{l}\text { PS-Resorcinarenes } \\
\text { Kleij, }(2017)^{28 c}\end{array}$ & $\mathrm{PO}$ & 1 & $\begin{array}{l}\text { neat, } 80^{\circ} \mathrm{C}, 18 \mathrm{~h} \\
p\left(\mathrm{CO}_{2}\right)=5 \text { bar }\end{array}$ & $99^{c}$ & 99 & 5.5 & 12 runs $(\mathrm{EH})$ \\
\hline 5 & $\begin{array}{l}\text { FIP-Im } \\
\mathrm{Ji},(2018)^{55}\end{array}$ & $\mathrm{PO}$ & 5 & $\begin{array}{l}\text { neat, } 80^{\circ} \mathrm{C}, 10 \mathrm{~h} \\
p\left(\mathrm{CO}_{2}\right)=10 \mathrm{bar}\end{array}$ & $99^{d}$ & 20 & 2 & 6 runs $(\mathrm{ECH})$ \\
\hline 6 & $\begin{array}{l}\text { PE-Im } \\
\text { This work }\end{array}$ & SO & 0.4 & $\begin{array}{l}\text { neat, } 100^{\circ} \mathrm{C}, 16 \mathrm{~h} \\
p\left(\mathrm{CO}_{2}\right)=1 \mathrm{bar}\end{array}$ & $88^{b}$ & 220 & 14 & 5 runs $(\mathrm{SO})$ \\
\hline 7 & $\begin{array}{l}{[\text { HDBU]I }} \\
\text { Dove, }(2019)^{29 c}\end{array}$ & $\mathrm{SO}$ & 10 & $\begin{array}{l}\text { neat, } 70^{\circ} \mathrm{C}, 4 \mathrm{~h} \\
p\left(\mathrm{CO}_{2}\right)=1 \text { bar }\end{array}$ & $96^{c}$ & 9.6 & 2.4 & 6 runs (AGE) \\
\hline 8 & $\begin{array}{l}\text { COF-JLU7 / TBAB } \\
\text { Liu, }(2018)^{56}\end{array}$ & $\mathrm{PO}$ & $0.5 / 5$ & $\begin{array}{l}\text { neat, } 80^{\circ} \mathrm{C}, 12 \mathrm{~h} \\
p\left(\mathrm{CO}_{2}\right)=1 \text { bar }\end{array}$ & $99^{b}$ & 198 & 16.5 & 5 runs $(\mathrm{ECH})$ \\
\hline
\end{tabular}

a) Reaction conditions and data as reported in original papers. SM: Starting material, EH: 1,2-epoxyhexane, PO: Propylene oxide, SO: Styrene oxide, ECH: Epichlorohydrin, AGE: Allyl Glycidyl Ether. ${ }^{\text {b) }}{ }^{1} \mathrm{H}$ NMR yield, ${ }^{\text {c) }}$ Conversion, ${ }^{\text {d) }}$ GC yield. 
The results obtained with catalyst $\mathbf{1}$ under atmospheric $\mathrm{CO}_{2}$ were also compared with other recyclable organocatalytic systems working under similar conditions. Using styrene oxide as substrate, a TON of 220 and a TOF of $14 \mathrm{~h}^{-1}$ were obtained with 1 (Table 2, entry 6). By comparison, DBU salts reported by Dove gave a TON of 9.6 and a TOF of $2.4 \mathrm{~h}^{-1}$ for the same substrate at $70^{\circ} \mathrm{C}$ (Table 2, entry 7). ${ }^{29 \mathrm{c}}$ Finally, similar results can be achieved using covalent organic frameworks COF-JLU7 in the presence of tetrabutylammonium bromide as a co-catalyst, as reported by Liu (Table 2, entry 8). ${ }^{56}$

Overall, our results show that thermomorphicpolyethylene-supported organocatalyst $\mathbf{1}$ can compete with other homogeneous organocatalysts in terms of activity while being fully recyclable.

\section{Conclusion}

In conclusion, we have reported the first imidazolium organocatalyst supported on thermomorphic PE. This catalyst was synthesized in one-step from polyethylene iodide and 1methylimidazole and was obtained with $92 \%$ yield on a gram scale. The catalyst was characterized by ${ }^{1} \mathrm{H}$ and ${ }^{13} \mathrm{C}$ NMR, SEC and MALDI-ToF MS. The reactivity of the catalyst has been studied on the synthesis of cyclic carbonates from $\mathrm{CO}_{2}$ and epoxides. The catalyst works under low $\mathrm{CO}_{2}$ pressure (1-10 bar) and moderate temperature $\left(100^{\circ} \mathrm{C}\right)$ at low loading $(0.4-4 \mathrm{~mol} \%)$. Under these conditions, a range of terminal and internal epoxides was converted to the corresponding cyclic carbonates with high yields and selectivities. Contrary to typical supported organocatalysts, the use of thermomorphic polyethylene as support enhances the catalytic activity. The recyclability of the catalyst has been studied and validated over five runs. Finally, we demonstrate that thermomorphic polyethylene is an excellent support for organocatalysts, which, with an improved reactivity and an excellent recyclability, combines the benefits of homogeneous and heterogeneous catalysis.

\section{Experimental Section}

General procedure for the ring-opening of terminal epoxides: The epoxide ( $9 \mathrm{mmol}, 1$ equiv) and catalyst $1(0.4$ mol\%) were added in a $45-\mathrm{mL}$ stainless steel autoclave with a magnetic stirrer, then the autoclave was sealed and the air was removed by a $\mathrm{CO}_{2}$ flux. The autoclave was charged with $\mathrm{CO}_{2}$ (5-20 bar) and the reactor was heated at $100^{\circ} \mathrm{C}$. After the reaction was complete (4-16 hours), the mixture was cooled to $0^{\circ} \mathrm{C}$ (ice bath), and the reactor was opened when it was cold to avoid any loss of material. The crude sample was analyzed by ${ }^{1} \mathrm{H}$ NMR. After addition of EtOAc to the residue, the catalyst was filtered and the filtrate was concentrated under reduced pressure to give the desired carbonates without any further purification.

General procedure for the ring-opening of internal epoxides: The epoxide (5 mmol, 1 equiv) and catalyst 1 (4 mol\%) were added in the $45-\mathrm{mL}$ autoclave with a magnetic stirrer, then the autoclave was sealed and the air was removed by a $\mathrm{CO}_{2}$ flux. The autoclave was charged with
$\mathrm{CO}_{2}$ (10 bar) and the reactor was heated at $100^{\circ} \mathrm{C}$. After 40 hours, the mixture was cooled to $0^{\circ} \mathrm{C}$ (ice bath), and the reactor was opened when it was cold to avoid any loss of material. The crude sample was analyzed by ${ }^{1} \mathrm{H}$ NMR. After addition of EtOAc to the residue, the catalyst was filtered and the filtrate was concentrated under reduced pressure. The residue was purified by column chromatography to give the desired carbonates.

Procedure for the recycling of the catalyst: The recycling of the catalyst was carried out following to the general procedure for terminal epoxides, using catalyst $1(1 \mathrm{~mol} \%)$ in the presence of $\mathrm{CO}_{2}(10$ bar $)$ at $100^{\circ} \mathrm{C}$ for 4 hours. After the reaction was complete, EtOAc $(30 \mathrm{~mL})$ was added into the crude mixture, then the suspension was filtered through paper membrane $(0.1 \mu \mathrm{m})$. The resulting solution was concentrated under reduced pressure to give the desired product $(93-97 \%$ yield) and the solid catalyst was dried under vacuum at $40^{\circ} \mathrm{C}$ for $4 \mathrm{~h}$ before reusing for the next run without any further purification. About $90-95 \%$ of the catalyst was recovered after each run. There are some unavoidable mechanical losses during the filtration step.

\section{Acknowledgements}

The Institut de Chimie de Lyon (ICL) is acknowledged for funding the "PE-Organocat" project that allows us to get preliminary results. The authors thank the French National Agency for Research for financial support through a Ph.D. grant to K.O. (ANR-19-CE07-0006-ThermoPESO). The Auvergne-Rhône-Alpes region is acknowledged for a partial support (SCUSI 2017009361 01) for Master 2 studies to A.A. The authors also thank the SAS PIVERT for a Ph.D. grant to N.D.V. (GENESYS program: project WP3P21-Bioaldehydes). This work was performed in partnership with the SAS PIVERT, within the frame of the French Institute for the Energy Transition (Institut pour la Transition Energétique (ITE) P.I.V.E.R.T. (http://www.institut-pivert.com)) selected as an Investment for the Future ("Investissements d'Avenir"). This work was supported, as part of the Investments for the Future, by the French Government under the reference ANR-001-01. F.D. and C.B. thanks the French National Agency for Research for the ANR LISIP-15-LCV4-005 funding. The authors would like to thank $F$. Delolme (UMR 5086, IBCP, Lyon, France) for MALDI-ToF MS analyses and the Centre Commun de RMN de Lyon (A. Baudoin, E. Chefdeville, C. Gilbert) for NMR analyses.

\section{References}

[1] R. K. Pachauri and L. A. Meyer, Climate Change 2014: Synthesis Report, Intergovernemental Panel Of Climate Change, Geneva, Switzerland, 2014.

[2] J. Y. S. Leung, S. D. Connell, I. Nagelkerken and B. D. Russell, Environ. Sci. Technol. 2017, 51, 12097-12103.

[3] N. US Department of Commerce, "ESRL Global Monitoring Division - Global Greenhouse Gas Reference Network," can be found under https://www.esrl.noaa.gov/gmd/ccgg/trends/global.html, 2018.

[4] K. M. K. Yu, I. Curcic, J. Gabriel, S. C. E. Tsang, ChemSusChem 2008, 1, 893-899.

[5] K. Sumida, D. L. Rogow, J. A. Mason, T. M. McDonald, E. D. Bloch, Z. R. Herm, T.-H. Bae, J. R. Long, Chem. Rev. 2012, 112, 724-781.

[6] a) T. Sakakura, J.-C. Choi, H. Yasuda, Chem. Rev. 2007, 107, 2365-2387; b) Q. Liu, L. Wu, R. Jackstell, M. Beller, Nat. Commun. 2015, 6, 5933; c) Q.-W. Song, Z.H. Zhou, L.-N. He, Green Chem. 2017, 19, 3707-3728; 
d) S. Dabral, Thomas Schaub, Adv. Synth. Catal. 2019, $361,223-246$.

[7] a) K. Huang, C.-L. Sun, Z.-J. Shi, Chem. Soc. Rev. 2011, 40, 2435-2452; b) X. Cai, B. Xie, Synthesis 2013, 45, 3305-3324; c) M. Börjesson, T. Moragas, D. Gallego, R. Martin, ACS Catal. 2016, 6, 6739-6749.

[8] B. Yu, L.-N. He, ChemSusChem, 2015, 8, 52-62.

[9] Y. Li, X. Cui, K. Dong, K. Junge, M. Beller, ACS Catal. 2017, 7, 1077-1086.

[10] H. Wang, Z. Xin, Y. Li, Top. Curr. Chem., 2017, 375, $1-26$.

[11] B. Schäffner, F. Schäffner, S. P. Verevkin, A. Börner, Chem. Rev. 2010, 110, 4554-4581.

[12] G. Girishkumar, B. McCloskey, A. C. Luntz, S. Swanson, W. Wilcke, J. Phys. Chem. Lett. 2010, 1, 2193-2203.

[13] a) D. J. Darensbourg, Chem. Rev. 2007, 107, 23882410; b) B. Grignard, S. Gennen, C. Jerome, A. W. Kleij, C. Detrembleur, Chem. Soc. Rev. 2019, 48, 4466-4514.

[14] a) M. S. Kathalewar, P. B. Joshi, A. S. Sabnis, V. C. Malshe, RSC Adv. 2013, 3, 4110-4129; b) G. Rokicki, P. G. Parzuchowski, M. Mazurek, Polym. Adv. Technol. 2015, 26, 707-761; c) A. Cornille, R. Auvergne, O. Figovsky, B. Boutevin, S. Caillol, Eur. Polym. J. 2017, 87, 535-552; d) P. Furtwengler, L. Averous, Polym. Chem. 2018, 9, 4258-4287; e) C. Carre, Y. Ecochard, S. Caillol, L. Averous, ChemSusChem, 2019, 12, 34103430 .

[15] For leading reviews, see: a) T. Sakakura, K. Kohno, Chem. Commun. 2009, 1312-1330; b) M. North, R. Pasquale, C Young, Green Chem. 2010, 12, 1514-1539; c) J. W. Comerford, I. D. V. Ingram, M. North, X. Wu, Green Chem. 2015, 17, 1966-1987; d) C. Martín, G. Fiorani, A. W. Kleij, ACS Catal. 2015, 5, 1353-1370.

[16] For more recent reviews, see: a) H. Büttner, L. Longwitz, J. Steinbauer, C. Wulf, T. Werner, Top. Curr. Chem. 2017, 375, 1-56; b) R. R. Shaikh, S. Pornpraprom, V. D'Elia, ACS Catal. 2018, 8, 419-450; c) A. J. Kamphuis, F. P. Picchioni, P. P. Pescarmona, Green Chem. 2019, 21, 406-448.

[17] a) J. Song, Z. Zhang, S. Hu, T. Wu, T. Jiang, B. Han, Green Chem. 2009, 11, 1031-1036; b) O. V. Zalomaeva, A. M. Chibiryaev, K. A. Kovalenko, O. A. Kholdeeva, B. S. Balzhinimaev, V. P. Fedin, J. Catal. 2013, 298, 179-185; c) Q. Han, B. Qi, W. Ren, C.He, J. Niu, C. Duan, Nat. Commun. 2015, 6, No. 10007; d) B. B. Lu, J. Yang, Y. Y. Liu, J. F. A. Ma, Inorg. Chem. 2017, 56, 11710-11720; e) P.-Z. Li, X.-J. Wang, J. Liu, H. S. Phang, Y. Li, Y. Zhao, Chem. Mater. 2017, 29, 9256-9261.

[18] a) Y. Xu, D. Yuan, Y. Wang, Y. Yao, Dalton Trans. 2017, 46, 5848-5855; b) Y.-M. Shen, W.-L. Duan, M. Shi, J. Org. Chem. 2003, 68, 1559-1562; c) P. A. Carvalho, J. W. Comerford, K. J. Lamb, M. North, P. S. Reiss, Adv. Synth. Catal. 2019, 361, 345-354.
[19] a) C. Martin, C. J. Whiteoak, E. Martin, M. MartinezBelmonte, E. C. Escudero-Adan, A. W. Kleij, Catal. Sci. Technol. 2014, 4, 1615-1621; b) J.A. Castro-Osma, K. J. Lamb, M. North, ACS Catal. 2016, 6, 5012-5025; c) X. Wu, M. North, ChemSusChem 2017, 10, 74-78.

[20] a) T. Ema, Y. Miyazaki, S. Koyama, Y. Yano, T. A. Sakai, Chem. Commun. 2012, 48, 4489-4491; b) R. L. Paddock, Y. Hiyama, J. M. McKay, S. T. Nguyen, Tetrahedron Lett. 2004, 45, 2023-2026; c) C. Maeda, J. Shimonishi, R. Miyazaki, J. Hasegawa, T. Ema, Chem. - Eur. J. 2016, 22, 6556-6563.

[21] a) J. Martínez, J. Fernández-Baeza, L. F. SánchezBarba, J. A. Castro-Osma, A. Lara-Sánchez, A. Otero, ChemSusChem 2017, 10, 2886-2890

[22] a) F. D. Monica, S. V. C. Vummaleti, A. Buonerba, A. De Nisi, M. Monari, S. Milione, A. Grassi, L. Cavallo, C. Capacchione, Adv. Synth. Catal. 2016, 358, 32313243

[23] For reviews focusing on organocatalytic systems, see: a) M. Cokoja, M. E. Wilhelm, M. H. Anthofer, W. A. Herrmann, F. E. Kühn, ChemSusChem 2015, 8, 24362454; b) B.-H. Xu, J.-Q. Wang, J. Sun, Y. Huang, J.-P. Zhang, X.-P. Zhang, S.-J. Zhang, Green Chem. 2015, 17, 108-122; c) M. Alves, B. Grignard, R. Mereau, C. Jerome, T. Tassaing, C. Detrembleur, Catal. Sci. Technol. 2017, 7, 2651-2684.

[24] a) V. Calo, A. Nacci, A. Monopoli, A. Fanizzi, Org. Lett. 2002, 4, 2561-2563; b) J. Q. Wang, K. Dong, W. G. Cheng, J. Sun, S. J. Zhang, Catal. Sci. Technol. 2012, 2, 1480-1484

[25] a) T. Werner, H. Büttner, ChemSusChem 2014, 7, 3268-3271; b) J. Großeheilmann, H. Büttner, C. Kohrt, U. Kragl, T. Werner, ACS Sustainable Chem. Eng. 2015, 3, 2817-2822; c) S. Liu, N. Suematsu, K. Maruoka, S. Shirakawa, Green Chem. 2016, 18, 4611-4615; d) Y. Toda, Y. Komiyama, A. Kikuchi, H. Suga, ACS Catal. 2016, 6, 6906-6910; e) Y. Toda, Y. Komiyama, H. Esaki, K. Fukushima, H. Suga, J. Org. Chem. 2019, 84, 15578-15589.

[26] a) J. Peng, Y. Deng, New J. Chem. 2001, 25, 639-641; b) H. Kawanami, A. Sasaki, K. Matsui, Y. A. Ikushima, Chem. Commun. 2003, 896-897; c) A.-L. Girard, N. Simon, M. Zanatta, S. Marmitt, P. Gonçalves, J. Dupont, Green Chem. 2014, 16, 2815-2825; c) S. Denizalti, RSC $A d v$. 2015, 5, 45454-45458; d) F. D. Bobbink, P. J. Dyson, J. Catal. 2016, 343, 52-61; e) J. A. Castro-Osma, J. Martínez, F. de la Cruz-Martínez, M. P. Caballero, J. Fernández-Baeza, J. Rodríguez-López, A. Otero, A. Lara-Sánchez, J. Tejeda, Catal. Sci. Technol. 2018, 8, 1981-1987.

[27] M. E. Wilhelm, M. H. Anthofer, M. Cokoja, I. I. E. Markovits, W. A. Herrmann, F. E. Kìhn, ChemSusChem 2014, 7, 1357-1360; b) P. Yingcharoen, C. Kongtes, S. Arayachukiat, K. Suvarnapunya, S. V. C. Vummaleti, S. Wannakao, L. Cavallo, A. Poater, V. D' Elia, Adv. Synth. Catal. 2019, 361, 366-373.

[28] a) C. J. Whiteoak, A. Nova, F. Maseras, A. W. Kleij, ChemSusChem 2012, 5, 2032-2038; b) L. Martínez- 
Rodríguez, J. Otalora Garmilla A. W. Kleij, ChemSusChem, 2016, 9, 749-755; c) T. Jose, S. Cañellas, M. A. Pericàs, A. W. Kleij, Green Chem. 2017, 19, 5488-5493.

[29] a) Z.-Z. Yang, L.-N. He, C.-X. Miao, S. Chanfreau, Adv. Synth. Catal. 2010, 352, 2233-2240; b) X. Meng, Z. Ju, S. Zhang, X. Liang, N. von Solms, X. Zhang, X. Zhang, Green Chem. 2019, 21, 3456-3463; c) N. FanjulMosteirín, C. Jehanno, F. Ruipérez, H. Sardon, A. P. Dove, ACS Sustainable Chem. Eng. 2019, 7, 10633-10640; d) F. Liu, Y. Gu, P. Zhao, J. Gao, M. Liu, ACS Sustainable Chem. Eng. 2019, 7, 5940-5945.

[30] a) S. Sopeña, E. Martin, E. Escudero-Adán, A. W. Kleij, ACS Catal. 2017, 7, 3532-3539; b) K. Takaishi, T. Okuyama, S. Kadosaki, M. Uchiyama, T. Ema, Org. Lett. 2019, 21, 1397-1401; M. Liu, P. Zhao, Y. Gu, R. Ping, J. Gao, F. Liu, J. CO 2 Util. 2020, 37, 39-44.

[31] a) S. Arayachukiat, C. Kongtes, A. Barthel, S. V. C. Vummaleti, A. Poater, S. Wannakao, L. Cavallo, V. D'Elia, ACS Sustainable Chem. Eng. 2017, 5, 63926397; P. Yingcharoen, C. Kongtes, S. Arayachukiat, K. Suvarnapunya, S. V. C. Vummaleti, S. Wannakao, L. Cavallo, A. Poater, V. D'Elia, Adv. Synth. Catal. 2019, 361, 366-373.

[32] M. Hong, Y. Kim, H. Kim, H. J. Cho, M.-H. Baik, Y. Kim, J. Org. Chem. 2018, 83, 9370-9380.

[33] a) J. Wang, Y. Zhang, ACS Catal. 2016, 6, 4871-4876; b) Triarylborane K. A. Andrea, F. M. Kerton, ACS Catal. 2019, 9, 1799-1809.

[34] a) W. Cho, M. S. Shin, S. Hwang, H. Kim, M. Kim, J. G. Kim, Y. Kim, J. Ind. Eng. Chem. 2016, 44, 210-215; b) S. Subramanian, J. Park, J. Byun, Y. Jung, C. T. Yavuz, ACS Appl. Mater. Interfaces 2018, 10, 9478-9484; c) X. Wu, C. Chen, Z. Guo, M. North, A. C. Whitwood, ACS Catal. 2019, 9, 1895-1906.

[35] a) Y. Du, F. Cai, D.-L. Kong, L.-N. He, Green Chem. 2005, 7, 518-523; b) J. Steinbauer, L. Longwitz, M. Frank, J. Epping, U. Kragl, T. Werner, Green Chem. 2017, 19, 4435-4445; c) R. A. Watile, K. M. Deshmukh, K. P. Dhake, B. M. Bhanage, Catal. Sci. Technol. 2012, 2, 1051-1055; d) J. Whiteoak, A. H. Henseler, C. Ayats, A. W. Kleij, M. A. Pericàs, Green Chem. 2014, 16, 1552-1559; e) Y. Xie, Z. Zhang, T. Jiang, J. He, B. Han, T. Wu, K. Ding, Angew. Chem. Int. Ed. 2007, 46, 72557258; f) W. Wang, C. Li, L. Yan, Y. Wang, M. Jiang, Y. Ding, ACS Catal. 2016, 6, 6091-6100; g) W. Wang, Y. Wang, C. Li, L. Yan, M. Jiang, Y. Ding, ACS Sustainable Chem. Eng. 2017, 5, 4523-4528; h) C. Li, W. Wang, L. Yan, Y. Wang, M. Jiang, Y. Ding, J. Mater. Chem. A 2016, 4, 16017-16027.

[36] a) G. Lai, J. Peng, J. Li, H. Qiu, J. Jiang, K. Jiang, Y. Shen, Tetrahedron Lett. 2006, 47, 6951-6953; b) L. Han, H.-J. Choi, S.-J. Choi, B. Liu, D.-W. Park, Green Chem. 2011, 13, 1023-1028.

[37] a) K. R. Roshan, G. Mathai, J. Kim, J. Tharun, G.-A. Park, D.-W. Park, Green Chem. 2012, 14, 2933-2940; b) L. Martínez-Rodríguez, J. Otalora Garmilla, A. W. Kleij, ChemSusChem 2016, 9, 749-755.
[38] a) J. Sun, J. Wang, W. Cheng, J. Zhang, X. Li, S. Zhang, Y. She, Green Chem. 2012, 14, 654-660; b) V. Besse, N. Illy, G. David, S. Caillol, B. Boutevin, ChemSusChem 2016, 9, 2167-2173.

[39] X.-D. Lang, X.-F. Liu, L.-N. He, Current Org. Chem. 2015, 19, 681-694.

[40] a) C. Kohrt, T. Werner, ChemSusChem 2015, 8, 20312034; b) T. Takahashi, T. Watahiki, S. Kitazume, H. Yasuda, T. Sakakura, Chem. Commun. 2006, 1664 1666.

[41] For a critical review about the immobilization of homogeneous catalysts, see: S. Hübner, J. G. de Vries, V. Farina, Adv. Synth. Catal. 2016, 358, 3-25.

[42] a) D. E. Bergbreiter, ACS Macro Lett. 2014, 3, 260-265; b) D. E. Bergbreiter, Thermomorphic Catalysts, in Recoverable and Recyclable Catalysts; Benaglia, M., Ed.; John Wiley \& Sons: Chichester, UK, 2009, pp117-147; c) D. E. Bergbreiter, Chem. Rev. 2002, $102,3345-3384$.

[43] C. Hobbs, Y.-C. Yang, J. Ling, S. Nicola, H.-L. Su, H. S. Bazzi, D. E. Bergbreiter, Org. Lett. 2011, 13, 39043907.

[44] I. Romanenko, S. Norsic, L. Veyre, R. Sayah, F. D’Agosto, J. Raynaud, C. Boisson, E. Lacôte, C. Thieuleux, Adv. Synth. Catal. 2016, 358, 2317-2323.

[45] a) R. Briquel, J. Mazzolini, T. Le Bris, O. Boyron, F. Boisson, F. Delolme, F. D'Agosto, C. Boisson, R. Spitz, Angew. Chem. Int. Ed., 2008, 47, 9311-9313; b) I. German, W. Kelhifi, S. Norsic, C. Boisson, F. D'Agosto, Angew. Chem. Int. Ed. 2013, 52, 3438-3441; c) W. Nzahou Ottou, S. Norsic, F. D'Agosto, C. Boisson, Macromol. Rapid Commun. 2018, 1800154.

[46] W. Nzahou Ottou, S. Norsic, I. Belaid, C. Boisson, F. D'Agosto, Macromolecules 2017, 50, 8372-8377.

[47] a) R. G. Lopez, C. Boisson, F. D'Agosto, R. Spitz, F. Boisson, D. Gigmes, D. Bertin, Macromol. Rapid Commun. 2006, 27, 173-181; b) R. G. Lopez, C. Boisson, F. D'Agosto, R. Spitz, F. Boisson, D. Bertin, P. Tordo, Macromolecules 2004, 37, 3540-3542.

[48] J. Steinbauer, A. Spannenberg, T. Werner, Green Chem. 2017, 19, 3769-3779.

[49] a) J. Langanke, L. Greiner, W. Leitner, Green Chem. 2013, 15, 1173-1182; b) N. Tenhumberg, H. Büttner, B. Schäffner, D. Kruse, M. Blumenstein, T. Werner, Green Chem. 2016, 18, 3775-3788; c) H. Büttner, J. Steinbauer, C. Wulf, M. Dindaroglu, H.-G. Schmalz, T. Werner, ChemSusChem 2017, 10, 1076-1079; d) L. Longwitz, J. Steinbauer, A. Spannenberg, T. Werner, ACS Catal. 2018, 8, 665-672.

[50] J. Meinwald, S. S. Labana, M. S. Chadha, J. Am. Chem. Soc. 1963, 85, 582-585.

[51] V. Laserna, G. Fiorani, C. J. Whiteoak, E. Martin, E. Escudero-Adán, A. W. Kleij, Angew. Chem. Int. Ed. 2014, 53, 10416-10419.

[52] P. Jaiswal, M. N. Varma, J. $\mathrm{CO}_{2}$ Util. 2016, 14, 93-97. 
[53] It should be noted that this comparison can not be exhaustive considering the huge number of (organo)catalytic systems reported to catalyze this transformation. For further comparison, see: a) M. Liu, X. Wang, Y. Jiang, J. Sun, M. Arai, Catal. Rev. 2019, 61, 214-269; ref $16 \mathrm{c}$ and ref $23 \mathrm{~b}$.

[54] H. Zhou, G.-X. Wang, W.-Z. Zhang, X.-B. Lu, ACS Catal. 2015, 5, 6773-6779.
[55] Y. Chen, R. Luo, J. Bao, Q. Xu, J. Jiang, X. Zhou, H. Ji, J. Mater. Chem. A 2018, 6, 9172-9182.

[56] Y. Zhi, P. Shao, X. Feng, H. Xia, Y. Zhang, Z. Shi, Y. Mu, X. Liu, J. Mater. Chem. A 2018, 6, 374-382. 


\section{FULL PAPER}

A Thermomorphic Polyethylene-Supported Imidazolium Salt for the Fixation of $\mathrm{CO}_{2}$ into

Cyclic Carbonates

Adv. Synth. Catal. Year, Volume, Page - Page

Kevin Grollier, Nam Duc Vu, Killian Onida, Ayman Akhdar, Dr Sébastien Norsic, Dr Franck D’Agosto, Dr Christophe Boisson, Dr Nicolas Duguet*

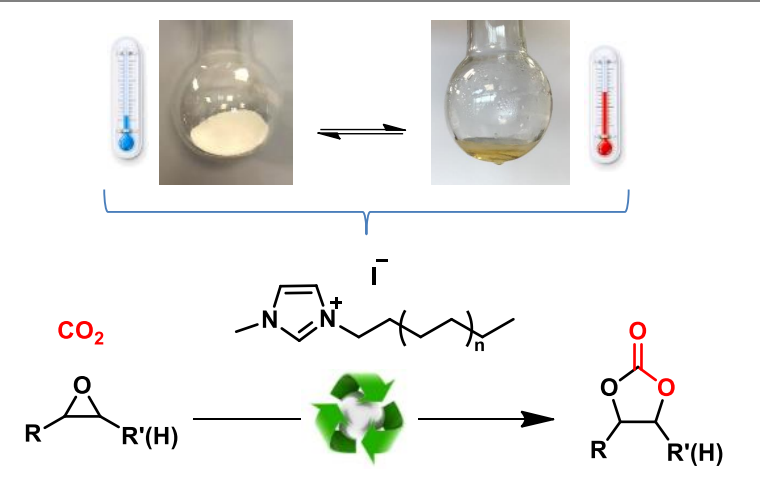

